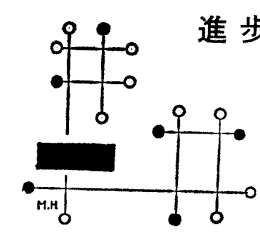

3. 炭化ウラン燃料

㴊跟でのべたように, 二酸化ウラン燃料の最も大きい 欠点は熱伝導度が小さいことであり，このことが燃料の 高温然焼時に扣ける性梊を複雑にしている。 そこで熱伝 導性のよい融点の高いウラン化合物の5ちで, 原子炉然 料として必要な性斦をもつたものが求められてきたので ある、なかでも炭化ウランははやくから注日され，多く の研究が行なわれ詳細な総報も発表されている(13)〜(16). 炭化物の5ちUC はウラン密度が大きく, 化学量論的に UC の組成をもつたものは被覆材との両立性もよいの で, ガス冷却炕, 有機減速炬の然料として, またプルト ニウムとの混合炭化物のかたちで高速炋燃料として有望 視されている．また， $\mathrm{UC}_{2}$ はその球状粘子を黑鉛中に分 散させたものとして, 高温ガス冷却炉の燃料に使用され ている.

炭化ウランは普通金属ウランと炭素または気体状の炭 化水素との反応によって作ることができる. また, 酸化 ウランや弗化ウランから直接炭化ウランを作る方法もあ る.この炭化ウランを燃料のかたちにする方法として， (i)压縮成型焼結泣, (ii) 振動充填法, (iii)ホットプレス法,

\section{セラミックス (II)}

上田隆 三*

(iv)アーク溶解法，(V)電子ビーム溶解法などが 研究さ

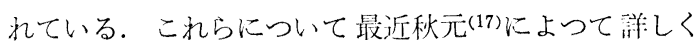

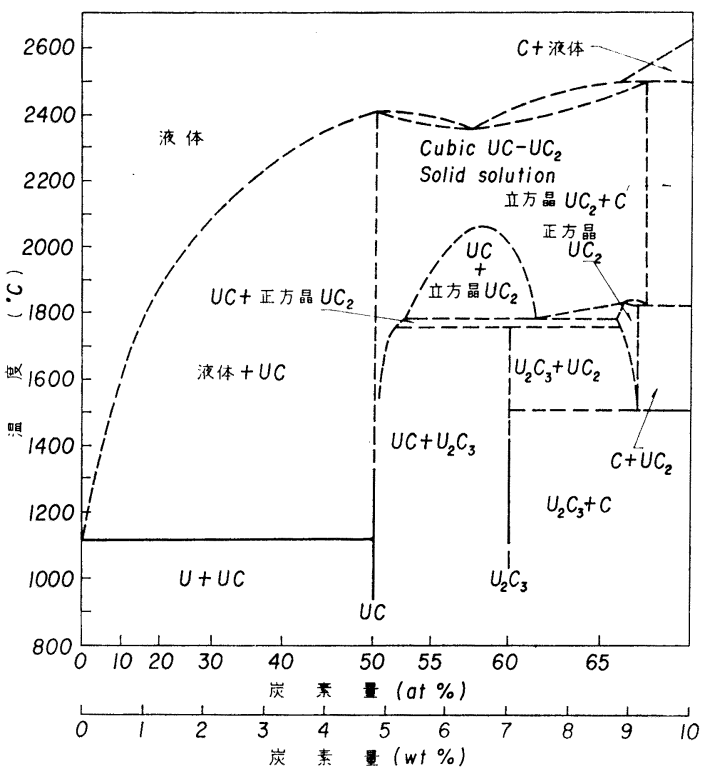

第8闵U-C系状態図(19)

第 1 表 ウラン化合物の性質

\begin{tabular}{|c|c|c|c|c|c|c|}
\hline & $\mathrm{UO}_{2}$ & UC & $\mathrm{UC}_{2}$ & UN & US & UP \\
\hline 理 論 $\begin{array}{c}\text { 密 度 } \\
\left(\mathrm{g} / \mathrm{cm}^{3}\right)\end{array}$ & 10.97 & 13.63 & 11.68 & 14.32 & 10.87 & 10.3 \\
\hline ウ ラン 密度 & 9.6 & 12.97 & 10.61 & 13.6 & 9.6 & 9.0 \\
\hline 絬 晶 構 造 & $\begin{array}{c}\text { 面心立方晶 } \\
\mathrm{CaF}_{2} \text { 型 }\end{array}$ & $\begin{array}{l}\text { 面心立j品 } \\
\mathrm{NaCl} \text { 型 }\end{array}$ & 立 才j 晶 & $\begin{array}{c}\text { 面心妾方晶 } \\
\text { NaCl 型 }\end{array}$ & $\begin{array}{l}\text { 面心立方晶 } \\
\mathrm{NaCl} \text { 型 }\end{array}$ & $\begin{array}{l}\text { 面心咅方晶 } \\
\mathrm{NaCl} \text { 型 }\end{array}$ \\
\hline 融 $\quad\left({ }^{\circ} \mathrm{C}\right) \quad$ 点 & $2,750 \pm 40$ & $2,400 \pm 100$ & 2.570 & $\begin{array}{l}2,850 \pm 30 \\
(2.5 \text { 気玨 })\end{array}$ & 2460 & $\begin{array}{c}2540 \\
(2730)\end{array}$ \\
\hline $\begin{array}{l}\text { 熱 伀 䀯 } \\
\left(\mathrm{cal} / \mathrm{sec} / \mathrm{cm} /{ }^{\circ} \mathrm{C}\right)\end{array}$ & $\begin{array}{l}0.08\left(100^{\circ} \mathrm{C}\right) \\
0.012\left(400^{\circ} \mathrm{C}\right) \\
0.008\left(100^{\circ} \mathrm{C}\right)\end{array}$ & $\begin{array}{r}0.06\left(100^{\circ} \sim\right. \\
\left.700^{\circ} \mathrm{C}\right)\end{array}$ & $\begin{array}{l}0.082\left(50^{\circ} \mathrm{C}\right) \\
\text { (密度 } 10.0)\end{array}$ & $\begin{array}{l}0.037\left(200^{\circ} \mathrm{C}\right) \\
0.042\left(400^{\circ} \mathrm{C}\right) \\
0.046\left(600^{\circ} \mathrm{C}\right) \\
0.049\left(800^{\circ} \mathrm{C}\right)\end{array}$ & \begin{tabular}{|l|}
$0.0275\left(100^{\circ} \mathrm{C}\right)$ \\
$0.0284\left(200^{\circ} \mathrm{C}\right)$ \\
$0.0298\left(300^{\circ} \mathrm{C}\right)$ \\
$0.0320\left(400^{\circ} \mathrm{C}\right)$
\end{tabular} & $\begin{array}{c}0.023 \\
\text { (密度 } 88.8 \% \text { ) }\end{array}$ \\
\hline
\end{tabular}

* 日本原子力研究所燃料開発部

(13) F.A. Rough and R.F.Dickerson: Nucleonics, 18 (1960) , No.3,74.

(14) B.R.T.Frost: J.Nucl. Mat., 10(1963), 265.

(15) F. Benesovsky ed.: Powder Metallurgy in Nuclear Age, Plansee Proceedings(1961), Metallwerk Plansee A.G., Reutte/Tyrol (1962).
まとめられているので, ここではふれないことにする. 炭化ウランは化学的に不安定であり, 酸化されやすく, また, 酸化ウランから炭化物を作る場合には酸素が残り

(16) J.Crane and E.Gordon : UNC-5080 (February $29,1964)$

（17）秋元：新金属工業, (1965) 1 月号 
やすいので, 製法に種々の工夫がなされている(18).

U-C 系の状態図を第 8 図(19)に示したが,然料物質とし ての化合物の安定性を知るために重要なものである。し かし，この状態図を多少修正する提案も行なわれている (20).また，炭化ウランと被覆材との反応を調べるため に, UC-Cr, UC-Fe, UC- $\mathrm{Fe}_{2}, \mathrm{UC}-\mathrm{Ni}$ 系の研究も行なわ れている(15).

\section{(1) UC}

UC の性質の主なる のを第1表に示した. 化学量 淪的な UC $(4.8 \mathrm{wt} \% \mathrm{C})$ からなる焼結体や，溶融として 作つた然料体は等軸のUC 結晶粒からなり, 原子炬然料 として使用するのに極めて望ましい形である。しかし実 際に化学量的な UC を製造することは，その状態図（第 8 図) からもわかるよ5になかなか困難であつて, 収率 もわるく高価となる，炭素量が 4.8 wt％より少なくな ると, 面心立方の UC の結晶粒の粒界に金属ウランが析 出したものとなり，炭素量が $4.8 \mathrm{wt} \%$ 以上になると， $\mathrm{UC}$ の結晶粒の (100) 面に板状の $\mathrm{UC}_{2}$ が析出してくる. この相違が燃料としての挙動に䄼々の影響を扣よぼすの で, 最近は $\mathrm{UC}_{1-x}$ 执よび $\mathrm{UC}_{1+x}$ についての照射挙動に 重点を执いて研究されている(21).

\section{(a) 核分裂ガスの放出}

UC からの核分裂ガスの放出は温度が高いほど，また， 照射量が多いほど大となる.一般に $\mathrm{UC}_{1+x}$ より $\mathrm{UC}_{1-x}$ の 方が放出しやすい. $\mathrm{UC}_{1-x}$ よりの核分裂ガスの放出は炭 素量が少なくなるほど多くなり，糨界の析出した金属ウ ランが溶解したり，その再配列がおこつたりすると多く なるようである， $\mathrm{UC}_{1+x}$ の化合物の場合には照射中の硈 歪により割れを生じ増加するといわれている.

$1000^{\circ} \mathrm{C}$ 以下では $\mathrm{UC}_{1+x}, \mathrm{UC}_{1-x}$ ともに核分裂ガスの放 出はきわめて少なく,たとえばアーク溶解した 4.6〜4.8 wt \% C の UC を最高温度 $780^{\circ} \mathrm{C}$ で約 $2 \times 10^{20}$ fissions $/ \mathrm{cc}$ 照射したものの核分裂ガス放出量は $0.04 \%$ 以下であり,

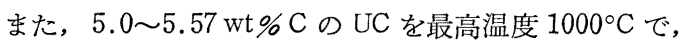
$10.6 \times 10^{20}$ fissions $/ c c$ 照射したものでも同程度といわれ ている.この放出量は拡散と表面よりの反跳により放出 されると考えた計算量とほほ一致する.

これに対して $1000^{\circ} \mathrm{C}$ 以上では, $\mathrm{UC}_{1-x}$ の場合にはさ きにも述べたように, UCの結晶粒々界に析出している 金属ウランの融解が抗こると, 計算值より予想するより

(18) L. E. Russell, R. G. Sowden, B.T.Bradbury, M.B.Waldron, H.J.Hedger and N.Parkinson: 第 3 回ジュネーブ会議 A/conf. 28/p/154(1964)

(19) F.A. Rough and W.Chubb: BMI-1554(1961).

(20) 山本, 原子力学会誌, 6(1964),134.

(21) T.J.Pashos, D. R. deHalas, D. L. Keller and L.A. Neimark: 第 3 回 ジュネーブ会議 A/conf. 28/p/240(1964).
はるかに多量の核分裂ガスが放出される.これに反して $\mathrm{UC}_{1+x}$ の場合は $1000^{\circ} \mathrm{C}$ 以上でも核分裂ガスの放出が極 わて少ない，たとえば，4.8～5.0 wt\% C の UCを 842 ${ }^{\circ} \mathrm{C}$ と $1180^{\circ} \mathrm{C}$ でそれぞれ $9.7 \times 10^{20}, 4 \times 10^{20}$ fissions $/ \mathrm{cc}$ 照射したものでも放出量は非常に少ない(1.3\%以下)と いわれている. また, 高然焼の場合も放出量は少なく, $5.21 \mathrm{wt} \% \mathrm{C}$ の $\mathrm{UC}_{1+x}$ を $16.0 \times 10^{20} \mathrm{fission} / \mathrm{cc}$, 平均中 心温度 $1060^{\circ} \mathrm{C}$ のときでも5\%にすぎないとい5．ただ， $\mathrm{UC}_{1+x}$ の場合は照射によつて割れが生じると，拡散で放 出する面も多くなり，反跳で核分裂ガスがとび出す面積 も大きくなるので，放出量が多くなることがある.

\section{(b) 照射による密度变化}

照射による体積膨張は $\mathrm{UC}_{1-x}$ の場合も $\mathrm{UC}_{1+x}$ の場合 もあまり変らないといわれている. しかし $U_{1-x}$ の場合 には炭菜量が少なくなる注ど，また金属ウラン $\beta \rightarrow \gamma$ の 変態点以上 $\left(770^{\circ} \mathrm{C}\right)$ になるとスウェリングが増加する.

\section{(c) 照射安定性}

$\mathrm{UC}_{1-x}$ も $\mathrm{UC}_{1+x}$ も照射により 熱查が生じると亀裂を 生ずる.この亀裂は $\mathrm{UC}_{1-x}$ の方が扣こりにくいが，それ はUC粒子の粒界に金属ウランが析出しているからだと 考えられる.

熱伝導特性をよくするために, 燃料物質と被覆材の間 に Na または NaKを入れることがあるが，その場合 $\mathrm{UC}_{1+x}$ では UC 中の準安定の $\mathrm{UC}_{2}$ が液体金属と反応し, $\mathrm{UC}_{2}$ の炭素が被覆材に移動し, 被覆材を炭化する. その 結果, 被覆材がもろくなつて亀裂を生ずる，炭素の移動 は $\mathrm{UC}_{2}$ がUCになるまでつづき，また $\mathrm{UC}_{1+x}$ が照射に より割れると液体金属との接触面積が大きくなり，炭素 の移動速度が大となる，この現象を拈さえるためには， 炭菜の移動を防ぐ何らかの工夫が必要であり，また，不 銹鋼の上5に炭化されやすい被覆材を用いないよ5にし なければならない。液体金属ボンディングの代りにへリ ウムや機械的なボンディングを行なつた方がよいが，被 覆材と接触すればある程度の炭化はさけられないだろ 3. $\mathrm{UC}_{1+x}$ は $\mathrm{UC}_{1-x}$ に比して照射挙動はすぐれている が,この被覆材への炭素の移動がこんごの一つの大きい 研究課題といえよう.

\section{(2) $\mathrm{UC}_{2}$}

高温ガス冷却炉の然料として黒鉛の中に炭素化ウラン 粒子を分散させたものが使用される．この炭化ウラン粒 子は，黒鉛中で高温度になるので $\mathrm{UC}_{2}$ 粒子が用いられ る. 黒鉛中に $\mathrm{UC}_{2}$ 粒子を分散させた然料は金属の被覆 管を用いることができないので，不滲透性黒鉛の鞘に入 れて用いるのが普通である，この場合最も大さい問題は 核分裂ガスの放出である．核分裂ガスの放出をできるだ け防ぐ方法として，(i) $U_{2}$ 粒子を $150 \sim 250 \mu$ の球状粒 
子とする. (ii) $\mathrm{UC}_{2}$ 粒子の表面を密度の高いセラミック スで被覆する 2 方法がとられる。然料粒子表面をセラミ ックで被覆してもそれが照射や熱サイクルで割れが生じ ては目的を果すことはできない，最近粒子表面を被覆す る方法が各国に和いて開発され試験されている(22) (24).

$\mathrm{UC}_{2}$ 粒子表面は一般にパイロリティク・カーボンで被 覆される. その方法は $\mathrm{UC}_{2}$ を高温に保ち, $\mathrm{CH}_{4}$ または $\mathrm{C}_{2} \mathrm{H}_{2}$ のような炭化水素を $\mathrm{He}$ または $\mathrm{H}_{2}$ のよ5なキャリ アガスとともに流し, $\mathrm{UC}_{2}$ 粒子の表面で熱分解させて被 膜を作るのである(24) (28)。 この熱分解条件によつて多 孔性の被覆や密度の高い層状や柱状のパイロリティク . カーボンの被膜を作ることができる．照射やサーアルサ イクルに強い被覆として， $\mathrm{UC}_{2}$ 粒子表面をまず多孔質の 被膜で被い, さらにその上を層状や柱状のパイロリティ ク・カーボンで二重,三重に被覆したものがよいといわれ ている. その代表的な例を第 9 図に示した。 パイロリテ

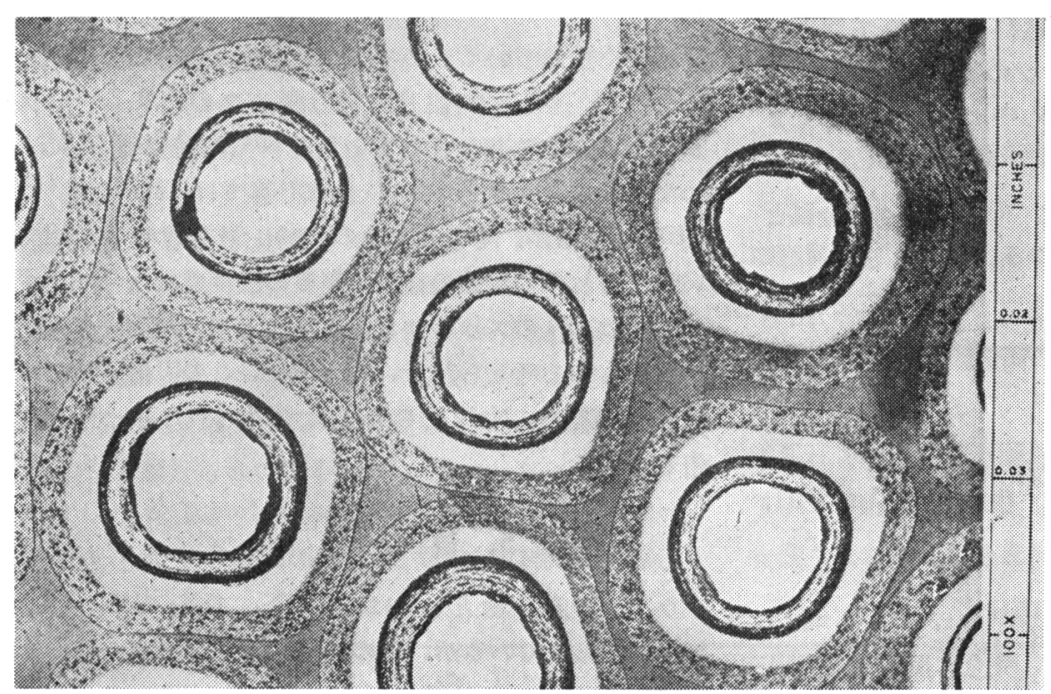

第 9 図 パイロリテイクカーボンで 3 重被覆した $\mathrm{UC}_{2}$ 粒子を黒鉛 中に分散さたもの ${ }^{(24)}$

イク・カーボンのほかに炭化ケイ素 $\mathrm{SiC}$ の被覆もあわせ て作ることも研究されている(23)(29).

(22) R.W.Dayton, J.H.Oxley and C.W.Townley: J.Nucl. Mat., 11 (1964), 1.

(23) J.M.Blocher, Jr., M.F.Browning, W.J.Wilson, V.M.Secrest, A.C.Secrest, R.B.Landrigan and J.H.Oxley: Nucl. Sci. Eng., $20(1964), 153$.

(24) C.W.Townley, N.E.Miller, R.L. Ritzman and R.J.Burian: ibid, 20 (1964), 171.

(25) F.L.CarlsenJr., E.S.Bomar and W.O.Harms: Nucl. Sci. Eng., 20(1964), 180.

(26) W.V.Goeddel: ibid, 20 (1964), 201.

(27) R.A.Reuter: ibid, $20(1964), 219$.

(28) H.G.Sowman, R.L.Surver and J. R. Jonson: ibid, $20(1964), 227$.

\section{4. 窒 化 ウ ラン UN}

炭化ウランよりも金属との両立性がよく, また空気中 での 安定性のよいものとしてUN が注目されている. UN は第 1 表に示したようにUCよりもウラン密度が高 く, 熱伝導度子第 10 図に示すよ 5 に $800^{\circ} \mathrm{C}$ 以上になる

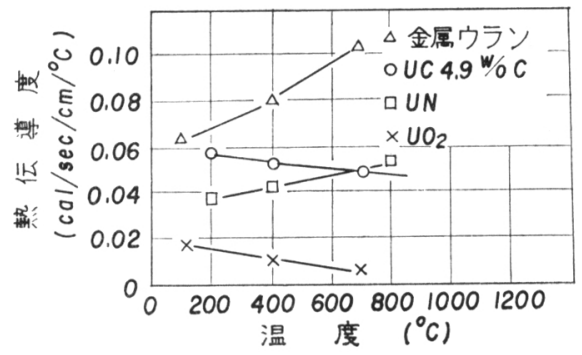

第 3 㘠金属ウラン, $\mathrm{UC}, \mathrm{UN}, \mathrm{UO}_{2}$ の熱伝導度(18)

とUC よりもよくなる傾向がある, また, 空気, 炭酸ガ ス, NaKなどに対して高温で も比較的安定である。ただ窒素 が熱中性子吸収断面積が大きい ために，少し濃縮したウランを 使用する必要あるが，将来ガス 冷却や液体金属泠却の動力炉の 燃料として使用される可能性が あり，ここ数年来各国に沶いて 研究が進められてさた(30)(31).

（1）UN の製法 UN を製造す る方法に種々ある。普通は金属 ウランの小片（ときには金属片 から水素化物を作り，それを熱 分解した 金属ウラン粉末)に直 接 1 気圧の窒素を約 $850^{\circ} \mathrm{C}$ で作 用させる.この反応で $N / U$ 比 が約 1.6 の高次窒化物が兄られ るが，これを真空中で $1300^{\circ} \mathrm{C}$ に加熱すると分解して $\mathrm{UN}$ となる。この他, $\mathrm{UO}_{2}$ や重ウラン酸アンモンに窒 素を反応させる方法も研究されているか゚，これらの方法 では $\mathrm{UO}_{2}$ や炭素が不純物として入りやすい.

かくしてえられたUN粉末を加圧成型焼結して高密度 にすることは困難であり, BMI では予めかためた UN をホットプレスして密度 $96 \%$ 以上のものを作つている.

(29) F.S.Martin, F.J.P.Clarke, R.W.M.D’Eye and D.T.Livey：第3 回ジュネーブ会議, A/conf.28/ $\mathrm{p} / 152(1964)$.

(30) R.M.Dell and M.A11butt: AERE-R 4253|(1963).

(31) J.Bugl and D.L.Keller: Nucleonics, 22 (1965), No. 9,66 . 
すなわち、 -80 メッシュの UN 粉末をゴム管に 振動充 媜し密度を 30〜40\% とする.これを 100,000 psi で泠間 圧縮すると密度 $70 \%$ 以上のものとなる.ささらにこれを モリブデン管の中に入れて $1490^{\circ} \mathrm{C} て ゙ 3$ 時間, $10,000 \mathrm{psi}$ の圧方のもとで加熱するのである.

城戸(32)らはUN 粉末をボールミルでよく粉确して圧 縮成型し, 焼結して, 密度 $93 \%$ 以上のものをえている。 この成型物中に不純物として含まれる酸素などについて 分析されていないが, この方法で高密度のものがえられ れば安価に作りうる。

このほか, 25 気圧位の 高圧の 窒素雾囲気中で 金属ウ ランを消耗電極としてアーク溶融する方法む開発されて いる. この方法は窒化反応とUN の融解とを同時に行 な5あのであるが，金属ウランの代りに予め窒化したウ ランを銅のさやに入れて電極とすると品質のよいるのが できるといわれている.その他種々の製法が研究されつ つある(17).

(2) UN の性質 UN の原子炉燃料としての主なる性 質を第 1 表にまとめた，窒化ウランの物理的，化学的掠

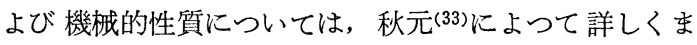
とめられているので参照されたい.

（3）金属との高温における反応 UN と種々の金属と の反応を第 2 表にまとめた。

第 2 表 UN と種々の金属との高温に括ける反応(31)

\begin{tabular}{|c|c|c|}
\hline 金属 & $\begin{array}{l}\text { 温度 } \\
\left({ }^{\circ} \mathrm{C}\right)\end{array}$ & \\
\hline \multirow[t]{3}{*}{$\mathrm{Al}$} & 400 & \multirow{15}{*}{ 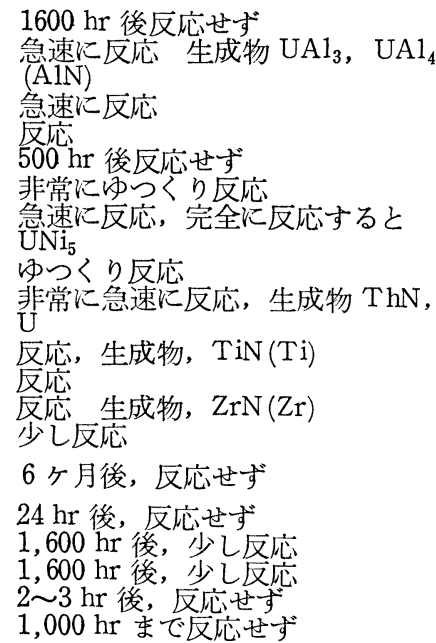 } \\
\hline & 500 & \\
\hline & 600 & \\
\hline $\mathrm{Cr}$ & 1,000 & \\
\hline $\begin{array}{l}\mathrm{Fe} \\
\mathrm{Mo}\end{array}$ & $\begin{array}{l}1,000 \\
1,000\end{array}$ & \\
\hline $\mathrm{Ni}$ & 1,000 & \\
\hline $\mathrm{Nb}$ & 1,000 & \\
\hline$T h$ & 1,000 & \\
\hline $\mathrm{Ti}$ & 1,000 & \\
\hline $\mathrm{Zr}$ & $\begin{array}{l}1,000 \\
1,000\end{array}$ & \\
\hline Zircaloy-2 & 600 & \\
\hline $\begin{array}{r}\text { stainless } \\
\text { steel }(304)\end{array}$ & 615 & \\
\hline & $\begin{array}{l}1,000 \\
1,200 \\
1,300\end{array}$ & \\
\hline W & 2,800 & \\
\hline $\mathrm{NaK}$ & 825 & \\
\hline
\end{tabular}

（4）照射効果 UN の照射効果については, まだ詳し い実験が行なわれていない.最近BMIにおいて密度 96〜

（32）城戸，高橋：日本原子力学会年会, (1965-4)

(33) 秋元：新金属工業, (1965) 2 月 p.1.
$99 \%$ の UN について 表面温度 $615^{\circ} \mathrm{C}$, 中心温度 $1260^{\circ} \mathrm{C}$ 然焼度 $3.8 \%$ U までの 実験が六つのキ+プセルについ て行なわれた(21)(31)。この実験は然焼度と $\mathrm{N}^{14}(\mathrm{n}, \mathrm{p}) \mathrm{C}^{16}$ 反応によつて生ずる水素が, UN の安定性に扣よぼす影 響を調べたものである。このキ+プセルのうち 1 個は試 料が $\mathrm{NaK}$ にじかに接触しているが，他の 5 個は不銹鋼 の被覆材の中に入れてある. 照射後の試験の結果による と， NaKにじかに浸してあつた試料は数個の破片に割 れていたが，これは熱丕によるものと考えられている. この割れは然焼度が高くなり，また，温度が高くなるほ ぞひどくなり，少さな破片が多くできる，不銹鋼で被覆 したものは, 被覆をとつた後も割れは認められなから た. 密度は最高 $6 \%$ まで減少しているが，このスウェリ ングは温度が高くなるほど大さくなつている，顕微鏡に よる組織の観察結果によると, 低温, 低照射のものでは ほとんぞ変化は認められないが, 3.8 at\% 燃燒, 中心温 度 $1260^{\circ} \mathrm{C}$ のものでは結晶成長が 認められ, 然料の中心 部には少さい丸い気泡が観察された。この気泡は結晶粒 界に多く生じている. クリプトンとキセノンの分析結果 によると，UN 中に生じた核分裂ガスの約 0.3 0.6\% が放出されたことを示している． $\mathrm{N}^{14}(\mathrm{n}, \mathrm{p}) \mathrm{C}^{14}$ 反応によ つて UN 中に生ずる 水素の量は計算では $14.8 \times 10^{-6} \mathrm{~g} /$ g UN であるが, その $2.6 \%$ のが，被覆管の中に出て いた．これらの実験の結果，窒素の核反応によつて生ず る水素は UN のスウェリングにはほとんど影響を与えて いないものと考兄られている．また，この照射実験では UN と被覆材や $\mathrm{NaK}$ との反応は認められなかつたと報 告している.

\section{5. 硫化ウラン}

ウランの硫化物としては US, $\mathrm{US}_{2}, \mathrm{U}_{3} \mathrm{~S}_{5}, \mathrm{US}_{3}, \mathrm{UOS}$ などが知られているが, その密度, ウラン密度, 融点, 安定性などから高温用 然料物質として対照となるのは US といえよう.その性質の主なるのを第 1 表に示した。 密度, ウラン密度は $\mathrm{UO}_{2}, \mathrm{UC}, \mathrm{UN}$ より少さいが, 熱伝 導度は $\mathrm{UO}_{2}$ よりも極めてよく, 焼結性のよいこと, 化 学的に比較的安定であること, 硫黄の熱中性子吸収断面 積は窒素のそれよりる小さいことなど核然料物質として 注目すべき性質をもつている.

\section{（1）US の 製 法}

硫化ウランを作るには一般につぎの四つの方法が用い られる。 (a) 金属ウランと $\mathrm{H}_{2} \mathrm{~S}$ または硫黄との反応 (b) $\mathrm{UH}_{3}$ と $\mathrm{H}_{2} \mathrm{~S}$ の反応，(c) 黒鉛の存在のもとでの $\mathrm{UO}_{2}$ と $\mathrm{H}_{2} \mathrm{~S}$ の反応, (d) $\mathrm{UCl}_{4}$ と $\mathrm{H}_{2} \mathrm{~S}$ との反応, US の製法はま だ実験室的規模で研究されているにすぎず，工業的にど の方法がよいかを決める段階には至つていない。 
高次の硫化物を真空中で高温に加熱すると最終的には US にまで分解するが，これには約 $1900^{\circ} \mathrm{C}$ の高温が必 要である.これに対して $\mathrm{US}_{2}$ に適量のU粉末をたは $\mathrm{UH}_{3}$

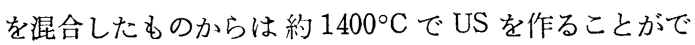

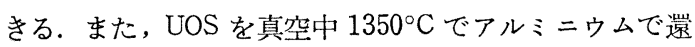
元する方法や， $\mathrm{UCl}_{4}$ を含んだ融解塩中で高次の硫化物 を電解還元する力法などがある．物性測定用の US を作 るには一般に, 金属ウラン粉末に一定量の $\mathrm{H}_{2} \mathrm{~S}$ を加兄” $550^{\circ} \mathrm{C}$ で反応させ，さらに約 $2000^{\circ} \mathrm{C}$ で均一化する方法 がとられいる.

このようにして作つた US の成型法についてはまだ余 り研究されていない。 また, 成型物について種々の性質 が測定されつつあるが, 不純物として $\mathrm{UO}_{2}$ やUOS が含 まれていることが多く，今後測定値は多少修正されてゆ くものと思われる.

\section{(2) US の照射効果 ${ }^{(21)}$}

UOS 2 wt \% 含んだ理論密度の $80 \%$ と $90 \%$ の焼結 した US を, Nb-1 wt\% Z r の被覆管に入れて, 被覆管の 温度 $790^{\circ} \mathrm{C} て ゙ 8.2 \times 10^{20}$ fissions $/ \mathrm{cc}$ まで燃焼させた実験 が行なわれた，その結果によると，被覆管の直径が 7.14 $\mathrm{mm}$ から $0.05 \mathrm{~mm}$ 近く変化している. 密度 $90 \%$ のもの からの核分裂ガスの放出は $0.21 \%$ であつたのに対して， 密度 $80 \%$ のものでは $1.2 \%$ であつた. 1 個の試料は中 心がとけて被覆管の直径が $0.2 \mathrm{~mm}$ ふくれていた.この 珷料を分析した結果, 非常に多量の UOS が含まれてい たこと判かつた．この試料よりの核分裂ガスの放出は約 $20 \%$ であつた。 また, 試料と被覆管との反応は認められ なかつたと報告されている.

$600^{\circ} \mathrm{C}$ で約 $1.5 \times 10^{6}$ fissions/cc まで 2 回の照射をく りかえし行なつた結果,焼結した $\mathrm{US}_{0.98}$ の物理的性質が
では $22 \%$ 增加したという。また， $1.5 \times 10^{16}$ fissions/cc の照射でUS の融点が $50^{\circ} \mathrm{C}$ 低くなつたといわれてい る.

\section{6. 燐化 ウ ラン UP}

最近研究がはじまつたばがりで, 製法もまだ研究され ている現状である. ANL や Hawell で(a) 金属ウラン粉 末と赤燐とを反応させる方法や，(b)金属ウランとフォ スフィンを反応させる方法, などが研究されている(17). UP 粉末をかためる方法もまだ適当な方法が見つかつて いないが，最近 ANLでホットプレス法で比較的大きい 測定用の試料が作れるようになつたようである.

UP の融点は $2540^{\circ} \mathrm{C}(34)$ で US よりも高く, 熱伝導度 も最近の研究によるとUSよりも高いといわれている. したがつて将来の高温用核然料物質として注目されはじ めたが，まだ種々の物性が測定されつつある現状といえ ょう(34).とくに高温に物性研究に重点がおかれている. 照射効果についての発表もまだほとんどない。

\section{7. プルトニウム化 合物}

プルトニウムは高速炉に使用する場合には，增殖比を 大きくとりらることが期待されるのて, 将来高速増殖炉 の然料として使用するのが本命と考えられる. しかし高 速炉の開発研究はまだ緒についたばかりであり, 各国に 扣いて意您的な研究が行なわれているので, 急速な発展 が期待されているが，その実用化は少しさきのことと考 号れる，そこで高速增殖炉の実用化までの間は熱中性 子炉で Pu-U238 燃料としてU235 の代りにプルトニウム を使うことも考える必要がある.

第 3 表 原子炉の燃料としで考えられるプルトニウム化合物とその性質

\begin{tabular}{|c|c|c|c|c|c|c|c|c|c|}
\hline \multirow{2}{*}{ 化合物 } & \multirow{2}{*}{ 絬 晶 } & \multirow{2}{*}{ 構 } & \multirow{2}{*}{$\begin{array}{l}\text { 密 度 } \\
\left(\mathrm{g} / \mathrm{cm}^{3}\right)\end{array}$} & \multirow{2}{*}{$\begin{array}{l}\text { プルトニ } \\
\text { ウム密度 } \\
\left(\mathrm{g} / \mathrm{cm}^{3}\right)\end{array}$} & \multirow{2}{*}{$\begin{array}{c}\text { 融 点 } \\
\left({ }^{\circ} \mathrm{C}\right)\end{array}$} & \multirow{2}{*}{$\begin{array}{l}\text { 硬 度 } \\
\text { (DPHN) }\end{array}$} & \multirow{2}{*}{$\begin{array}{c}\text { 発生ガス } \\
\text { (a) }\end{array}$} & \multicolumn{2}{|c|}{ 原子炉の型式 (d) } \\
\hline & & & & & & & & 高 速 & 熱中性子 \\
\hline $\begin{array}{l}\mathrm{PuN} \mathrm{PuO}_{2} \\
\mathrm{PuC} \\
\mathrm{PuS} \\
\mathrm{PuP} \\
\mathrm{PuAl}_{2} \\
\mathrm{PuSi}_{2} \\
\mathrm{PuAs} \\
\mathrm{PuTe} \mathrm{PuB}\end{array}$ & 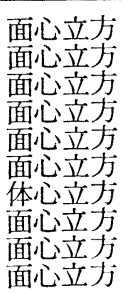 & $\begin{array}{l}\mathrm{NaCl} \text { 型 } \\
\\
\mathrm{NaCl} \text { 型 } \\
\mathrm{NaCl} \\
\mathrm{NaCl} \text { 型 } \\
\mathrm{Cu}_{2} \mathrm{Mg} \text { 型 } \\
\mathrm{ThSi} \\
\mathrm{NaCl} \text { 型 } \\
\mathrm{NaCl} \\
\mathrm{NaCl} \text { 型 }\end{array}$ & $\begin{array}{r}14.25 \\
11.46 \\
13.6 \\
10.60 \\
9.87 \\
8.06 \\
9.08 \\
10.39 \\
10.33 \\
\approx 13.85\end{array}$ & $\begin{array}{c}13.47 \\
10.1 \\
13.1 \\
9.36 \\
8.74 \\
6.57 \\
7.35 \\
7.9 \\
6.74 \\
\approx 13.25\end{array}$ & $\begin{array}{c}2800 \\
2360 \\
1650 \\
2460 \\
\text { (b) } \\
1540 \pm 50 \\
1795 \\
\sim 2000 \\
\sim 2000 \\
2030\end{array}$ & $\begin{array}{c}580 \\
105 \\
600 \sim 750 \\
\overline{2} \\
235 \\
550 \\
447 \sim 505 \\
\simeq 55 \\
= \\
=\end{array}$ & $\begin{array}{l}<0.15 \\
<0.15 \\
\text { 少 } \frac{\text { 量 }}{<} \\
<0.20 \\
<0.05 \\
<0.05 \\
<0.05 \\
\text { 少 量 } \\
\text { 少 } \\
<0.15\end{array}$ & $\begin{array}{l}8 \\
\frac{8}{8} \\
\frac{8}{8}\end{array}$ & $\begin{array}{l}8 \\
8 \\
8 \\
\frac{8}{-} \\
\overline{0}\end{array}$ \\
\hline
\end{tabular}

(a) 核反応により化合物中に生じたガス量と核分裂ガス量の容積比

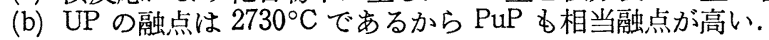

(c) ボロンは $\mathrm{B}^{11}$

(d) 高速炉，熱中性子炉にそれぞれ適したものに○が付しである.

大変変化したといら報告がある.最初の $7 \times 10^{15}$ fissions/ cc の照射では微小硬度が 75\% 増加したが，第二の照射
(34) ANL-6717,(April 1963)-6912 (June 1964), 7003 (January 1965). 
BMI の Keller ら ${ }^{(35)}$ はプルトニウム化合物のうちで高 速炉，扤よび熱中性子炉の然料として適当なるのとして 第 3 表に示した化合物をあげている．この撰択にあたつ ては, 原子炉の然料として必要な性質をもつた化合物の うち，まず融点が $1300^{\circ} \mathrm{C}$ 以上のものを選んでいる．ま たそのなかから原子炉材料との両立性, 相の安定性, 中 性子吸収の小さいもの, 製法の容易さなどの点を考㝋て 第 3 表の 10 の化合物を選んだのである. 第 3 表にはそ の性質も付した.

現在のところ窒化物, 二酸化物, 怙よび炭化物が最も 可能性のあるものとして研究が進められている. 窒化物 PuN は P-N 系で今日までみいだされているただ一つの 化合物であるが， $2000^{\circ} \mathrm{C}$ 以上で分解する 欠点をむつて いる. $\mathrm{PuO}_{2}$ はプルトニウム酸化物の5号最も高次のる ので, 酸化零囲気中で安定である. しかし, 非酸化零囲 気中では $1200^{\circ} \mathrm{C}$ 以上で容易に還元されたり，また，金 属と接して還元されて他の安定な酸化物になりやすい性 質がある. $\mathrm{PuO}_{2}$ については比較的研究されていないが, $(\mathrm{Pu}, \mathrm{U}) \mathrm{O}_{2}$ 燃料については多くの研究が行なわれてい る.

炭化物は酸化物についで研究されている. $\mathrm{PuC}, \mathrm{Pu}_{2} \mathrm{C}_{3}$ $\mathrm{PuC}_{2}$ は加圧成型焼結法や融解鋳造の 方法によつて成型 物とすることがでさる. $\mathrm{Pu}_{2} \mathrm{C}_{3}$ や $\mathrm{PuC}_{2}$ はプルトニウム 密度が低い点や被覆材へ炭素をとられ易いとい5 久点が あるので, PuC が最も注目されている.PuC は增殖炉で は $(\mathrm{Pu}, \mathrm{U}) \mathrm{C}$ 固溶体の形で用いられる可能性が多い。ま た $(\mathrm{Pu}, \mathrm{U}) \mathrm{C}_{2}$ はガス冷却の熱中性子炉に用いられるだる 5.PuC の電気抵抗は室温で 266 microhm-cm である. 熱伝導度はUC の約 20\%にすぎないが，(Pu,U)C の固 溶体にするとUC の 75\% 位にまであげることができる. $\mathrm{PuC}$ は上記の上5に燃料としてよい点をもつて打り, 研 究が目下寸すめられているので，今日までまだ判つてい

(35) W.M.Pardue, V.W.Storhok, R.A.Smith and D.L.Keller: BMI-1698(October 29, 1964).
ない性質もそのうちにもつと明確となつてくるだろう。 しかし，この然料の欠点はUC と同様に 化学量論的な PuC を製造することが仲々難かしいことと, 融点が比較 的低い $\left(1654^{\circ} \mathrm{C}\right)$ ことである。

PuS の性質はUS 似ていて, 高融点の金属と $2200^{\circ} \mathrm{C}$ まで，他の 金属構成材料と $800^{\circ} \mathrm{C}$ まで両立性があり， 種々の気体や冷却材との両立性もよいと思われる.PuS はまだ研究がはじまつたばかりで, 基礎的な性質も十分 判つていないが，核的に，すぐれた特長もるつているの で, 将来性が期待されている.

$\mathrm{PuP}$ は面心立方晶であること，プルトニウム密度の高 いことや，融点が高いことなどの長所をもつている. $\mathrm{PuP}$ 以上の高次の燐化物がないので, PuP 一相のものを 作るのが困難でないことも特長といえる.

$\mathrm{PuAl}_{2}$ は立方晶であることと照射の安定性のよいこと などの長所をもつている. しかしプルトニウム密度が比 較的低いので，高出力の高速炉飞用いることは困難で， 低温の水炬燃料として用いられる可能性がある. しかし 熱伝導度のよいことや製造の容易であることが期待され ている.

これらの化合物は照射を受けると， $(n, \alpha),(n, p)$ の 核反応が接こり，核分裂ガス以外にガスが発生するが， その量は第 3 表に示したように核分裂ガスに比して大変 少ないので, 闒題とする必要はない。

以上のべたよ5に $\mathrm{PuO}_{2}, \mathrm{PuC}$ 拈よび PuN が現在われ われがもつている知識からは原子炉然料として最もポテ ンシャルの高いものである。なかでも $\mathrm{PuO}_{2}$ 拉よび $\mathrm{PuC}$ については，すでに $\mathrm{UO}_{2} ， \mathrm{UC}$ に関する十分な知見が蓄 積されてきているので, (Pu, U $\mathrm{O}_{2},(\mathrm{PuU}) \mathrm{C}$ の形での 照射研究港重点を拈いて研究が進められつつある.PuN, PuS, PuP はその将米性から目下実験宰的な研究で種々 の物性值や化学的性質, 製法などが研究されている段階 といえよう。

\section{特 許 量 報 (4)}

$\diamond$ 昭和 40 年 7 月 30 日公告：一(つつきき)

電気鉄板の製造法 [昭 40-16653 千代田区 富士製鉄 $\mathrm{KK}$ ] wt $\% \mathrm{Mn} 0.1 \sim 0.7, \mathrm{P}<0.2, \mathrm{As}<0.3, \mathrm{Sn}<0.1$, $\mathrm{Ni}, \mathrm{Co}, \mathrm{Cu}, \mathrm{Mo}<0.2$ 脱 $\mathrm{C}$, 脱 $\mathrm{N}$ 後 $5 \sim 25 \%$ 冷圧, 焼鈍. 高誘導值をもつ無硅素電磁鋼帯の製造方法 [昭 40-16654 神戸市川崎製鉄 K K ] wt \% C 0.01 0.15, Mn 0.2 0.8 , Si $0 \sim 0.1$ 急冷処理後冷圧, 焼鈍.

真空スイッチ用接点 [昭 40-16655 千代田区. 三菱電機 $\mathrm{KK}] \quad \mathrm{wt} \% \mathrm{Cu} 30 \sim 50, \mathrm{C} 0.2 \sim 1$ 残 $\mathrm{Ni}$.

機械的摺動対部材 [昭 40-16656 千代田区 日本ピス卜 ンリングKK] wt\% 8〜25, Sn 5〜 17, $\mathrm{Zn}<2, \mathrm{P}<1$, 残 $\mathrm{Cu}$ の超鉛含有銅合金と硬質クロムとを相対的摺動面と して組合せる.
金属類の低圧鋳造機の改良〔昭 40-16657 上田计 日信 工業KK]

優良リムド鋼塊の製造法〔昭 40-16658 千代田区 富士 製鉄 K K ] 凝固をはじめりム層を形成した時期に未凝 固の溶鋼中に Mn あるいは Fe-Mnを投入.

小型絶縁基板の電解鍍金方法 [昭 40-16659 名古屋计 日本碍子 $\mathrm{K} K$ ]

長い金属線状体のメッキ装置〔昭 40-16660 新缩区 東 京特殊電線 $\mathrm{K} \mathrm{K}$ ]

ニッケル, 鉄およびモリブデンの 3 元合金の電着法; 低 Hk の鉄・ニッケル・砒素合金の電着法 (関連 2 件) [昭 40-16662；16663 優先権主張 2 件とも 1962.10.31(米 国)米国 スペリ ランドューポレーション] 電子ビーム溶接方法〔昭 40-16664 三鷹市 日本電子 $\mathrm{KK}$ ] 